\title{
The Bodleian Library of the University of Oxford
}

\section{Ned Irwin}

One of the world's great academic libraries, the Bodleian is both a unique institution (in its contents and arrangement) and one familiar with the problems affecting all modern academic libraries. It finds itself blessed by its past, being rich in collections of rare books, illuminated manuscripts, and personal papers. Yet it is burdened by this tradition when forced to remain a 100 percent retention library in a rapidly expanding information society or a nonlending facility as information collectors grow more interdependent. Like all libraries, the Bodleian is coming to grips with the twenty-first century.

$x$ ford is a city of libraries. One may think of spires in morning mists at mention of its name, but its libraries are less ephemeral and of greater value. There are some 100 libraries associated with the university town, and its greatest bibliographic treasure is the Bodleian Library.

The library recently completed the celebration of its 500th anniversary: Duke Humfrey Library was completed in $1488 .{ }^{1}$ The library has grown in proportion to its age since its refounding in 1602 by Sir Thomas Bodley (for whom it is named). Today it has a staff of 370 (with approximately 84 professional librarians) and extends into at least seven buildings from its original space in Duke Humfrey. It houses over 5.1 million volumes, 136,000 manuscript volumes, over 5,000 incunabula, 994,000 maps, 252,000 microforms, and 50,000 current serial titles. ${ }^{2}$

The Bodleian has been a copyright library in Britain since 1610. It thus receives a copy of every book published in the United Kingdom. ${ }^{3}$ The collection grows at a rate of 1.5 miles of shelving a year. ${ }^{4}$ The annual operating budget is currently $£ 5.5$ million ( $\$ 8.8$ million). In the most recent fiscal year figures this included as follows: salaries, £3.5 million ( $\$ 5.6$ million); books and periodicals $£ 1.3$ million ( $\$ 2$ million) (excluding those materials received free under copyright privilege); and conservation, $£ 100,000(\$ 160,000)$.

In addition to being a copyright library, the Bodleian has two other distinctive features that differ from the typical university library. It is a nonlending library, and it is a 100 percent retention facility. Both aspects have historical examples.

During the English Civil War, Charles I (making Oxford his seat of government) requested to have a book brought from the Bodleian to him. The request was refused by Bodley's librarian. No action was taken against the librarian. Sometime later, showing complete political impartiality and independence, the librarian also refused a request to lend a book to Oliver Cromwell. ${ }^{6}$

The idea that the Bodleian should throw nothing away once it enters the library was learned the hard way. A librarian re-

Ned Irwin is Special Collections Librarian/Archivist at the Chattanooga-Hamilton County Bicentennial Library, Chattanooga, Tennessee 37402.

The author wishes to express his appreciation to the following Bodleian staff for their assistance in his research at Oxford: David Vaisey, W. H. Clennell, Alan Bell, Richard Bell, Mary Clapinson, Allan Lodge, Charles Mould, Adrian Roberts, Julian Roberts, Stephen Tomlinson, Michael Turner, and Peter Warren. 
ceiving the second Shakespeare folio and believing it a revised, improved version of the first threw out the first folio of Shakespeare, which the Bodleian had purchased new. ${ }^{7}$

\section{ORGANIZATION AND COLLECTIONS}

Because the Bodleian serves as the central library of the University of Oxford, the university statutes authorize a twentytwo-member body known as the Curators to serve as the governing board (similar to a library board). The Curators are chosen from among the faculty of the colleges of Oxford. As the size of the body and schedules limit frequent gatherings, a small group of its members serve on a standing committee that meets once a week with the Bodley's librarian or secretary to discuss current library business. The Curators board establishes the general direction and rules for the library's operations but is not involved in its daily functioning.

The daily management of the library is in the hands of Bodley's Librarian and staff (see figure 1).

\section{Bodley's Librarian}

Bodley's current Librarian, David Vaisey, is the twenty-second Librarian in succession since the appointment by Bodley of the first Librarian, Thomas James, in 1602 . This is a remarkably small number in the nearly 400 years the post has existed.

Vaisey, who became Librarian in 1986, was previously Keeper of Western Manuscripts. His tenure has seen the Bodleian progress in its development of an online catalog system and increase outside fundraising efforts to strengthen all aspects of the library, especially to help fund a major retrospective conversion of its manual cat- alogs. In another major move to improve library services, a department of reader's services was created in 1988 with Richard Bell as its head.

Bodley's Librarian sees several problems to be faced in the near future: ${ }^{9}$

1. Because the library is housed in several buildings, a large staff (with the attendant expenses) is required at a time of decreasing government funding to the university and library.

2. The large collection, containing many old and fragile materials housed in buildings of unusual antiquity, leads to many conservation problems. Many conservation solutions will be expensive to implement.

3. The 100 percent retention system may be less feasible in terms of increasing expense and lack of space in the electronic age.

None of these problems is likely to be solved easily or quickly.

\section{Secretary of the Bodleian}

The secretary at the Bodleian, as in most British institutions, is the chief administrative officer of the organization. The current secretary, Charles Mould, handles the financial operations of the library, deals with personnel matters, and oversees the maintenance and security of the library's historic buildings.

Finances are a major issue in the wake of government funding cuts during the Thatcher administration. Oxford and its library are currently in the middle of a fiveyear period, 1986-91, that will see an overall reduction in funding of 11 percent. Since the summer of 1988 the Bodleian has been engaged in a major fund-raising campaign seeking to raise the monies for

Curators

Bodley's Librarian
Department of
Western Manuscripts

\begin{abstract}
Department of
\end{abstract}
Department of
Keeper of
Printed Books the Catalogue
Secretary

FIGURE 1.

Bodleian Library Organizational Chart 
maintaining and hopefully expanding the library's collections and services. Some $£ 1.5$ million ( $\$ 2.5$ million) have been contributed to date. ${ }^{10}$

Many changes have occurred in recent years regarding personnel matters. At one time Bodleian staff did not have contracts. Today they do. All professional staff are given tenure after completing a probationary period. It is not uncommon to meet staffers who have spent their entire careers within Bodley walls. More formal training programs for staff have been instituted. In keeping with the times, the Bodleian now has a "Code of Practice on Sexual Harrassment."

\section{Department of Western Manuscripts}

Current Keeper of Western Manuscripts Mary Clapinson is the first woman to hold a keepership in the Bodleian. This unit of the library houses a treasure trove of manuscripts, personal papers, and illuminated manuscripts produced over the centuries in most of the western languages. Its materials include an esoteric range from St. Margaret's Gospel (eleventh century) to the personal papers of J.R.R. Tolkien (twentieth century) and much else both before and since. The earliest item is on papyrus from about the second century B.C.

Much of the department's collections were gathered during the seventeenth to the nineteenth centuries. It is especially strong in materials related to English history. For example, the Clarendon papers and the Atlee papers are located here. There has been a major effort to acquire the papers of persons eminent in literary and public life.

Mary Clapinson notes that the constraints of space are forcing a more selective attitude to be taken toward what is acquisitioned by the library. The movement now is to build on existing holdings rather than trying to fill gaps in weak or uncollected subject areas. ${ }^{11}$

\section{Department of Oriental Books and Manuscripts}

A Chinese specialist, Adrian Roberts, is current Keeper of Oriental Books and Manuscripts. As the title implies, this department covers a broad range of materi- als produced in a broader range of languages. The principal languages collected are those of the Middle Eastern (especially Hebrew and Arabic); central Asia, the Caucasus, Mongolia, Tibet, and the Far East (chiefly Chinese, Japanese, and Korean); and southeast Asia.

The many languages and dialects of India, Sri Lanka, and Pakistan are excluded, as these are collected by the Indian Institute Library. However, this material is housed and maintained by the department for the institute's use.

The department is especially strong in Hebraica (Bodley himself was a Hebrew scholar), while the Wardrop collection of Georgian is the largest in the language outside the Soviet Union. There are over 1,500 Arabic manuscripts and over 2,000 in Persian. Edward Fitzgerald turned to the Bodleian for the manuscript used for his translation of the Rubaiyat of Omar Khayyam.

In whatever area collected, the emphasis is to provide material to support the faculty of Oriental languages in Oxford. For covering such a vast front the Bodleian department is small when compared to a university like Harvard, which has a fulltime staff of about twelve, plus clerical workers to maintain its collection. Oxford is stretched to provide services with a staff of six.

\section{Department of Printed Books}

Deputy Librarian Julian Roberts is also Keeper of Printed Books. He notes that the first books in Oxford's library came in the medieval period and were copies from books abroad. The library itself was first formed about 1488 to house a donation of illuminated manuscripts given by Humphrey, Duke of Gloucester. ${ }^{12}$

But the need for a central library for the university soon faded as movabletype-printed books became widely available. Unlike unique illuminated manuscripts, which could only exist in one place, Oxford colleges could afford to acquire copies of printed books for their own collections. Thus in time the original central library was dispersed. About 100 years later, Sir Thomas Bodley reestablished a central library. This persists today as the 
Bodleian Library. Once again colleges find they have neither the space nor funds to acquire the growing printed material.

With increasing expenses and declining revenues, the department now concentrates on filling the gaps left from periods in the Bodleian's history when the copyright deposit privilege was not always rigorously applied. Funds are also used to purchase foreign books not falling under the copyright privilege and to acquire important books missed in the pre-1610 period (before copyright privilege). The British government has also provided support funding to buy "heritage" materials. A recent example for Oxford is its purchase of the Opie collection of children's books.

\section{The Catalog and Reference Services}

The Bodleian's intellectual access system is as unique as the institution that houses it. Not one but four catalogs must be used by a researcher in making a bibliographic search-the (1) pre-1920, (2) post1920, (3) interim, and (4) online catalogs.

\section{"The Bodleian is primarily a research library for graduate students and fac- ulty who will already have some command of the field in which they are researching."'}

Two points need to be made regarding the use of the catalogs. First, the researcher must know when a book was published (or else check each catalog). Second, the name of the author must be known for all but the online catalog are author-entry catalogs. The implication in this system is that the Bodleian is primarily a research library for graduate students and faculty who will already have some command of the field in which they are researching.

1. Pre-1920 catalog. This catalog lists books published before 1920 by author. Formerly handwritten guard books, the current version consists of bound volumes of computer printout sheets.

2. Post-1920 catalog (1920-1985). This catalog lists books published from 1920 until about 1985, when the catalog was closed. Again it is an author entry listing and consists of large, bound volumes containing pasted entries. This type of catalog is known as a "movable slip" catalog. Such entries can be moved down the page as new entries are published. This is a labor-intensive activity and was an impetus for developing an online system.

3. Interim catalog (1985-1988). The last manual catalog, it lists books published during the years after the closing of the post-1920 catalog. As the name indicates, it was developed to serve as a temporary and less labor-intensive measure while an online catalog system was being created. It is a card index catalog, not unlike those in the United States, except it is an author entry-only system and, like its predecessors, follows the Bodleian's own in-house cataloging rules of 1939.

4. Online catalog (since September 1988). The Bodleian has developed the OLIS (Oxford University Library System) online catalog using the DOBIS/LIBIS system. At this writing it contains nearly 50,000 entries. All four catalogs will be required for some time to come.

The OLIS system does provide subject entry access for the first time in the Bodleian, as well as access by author, title, publisher, ISBN/ISSN number, shelf number, or copy number. Boolean logic can be used. Cataloging based on AACR2 MARC format with LC subject headings has been adopted as well. Terminals are available in the Lower Reading Room. The system may also be searched by any terminal with access to the university's data network or to the Joint Academic Network (JANET).

In the past subject access was aided to some extent because the library reading rooms were arranged in broad subject areas. This means that subject bibliographies and other useful reference materials are available to help access the material of the Bodleian, along with assistance from the knowledgeable subject specialists.

A massive retrospective conversion of the Bodleian catalog is foreseen. According to Vaisey, converting the last movable slip catalog (1920-1985) to MARC format 
and the OLIS system will take some forty people thirteen years and cost an estimated $£ 3.5$ million ( $\$ 5.6$ million). ${ }^{13}$ Monies for this project is one of the major objectives of the current fund-raising campaign.

Once one has found the item in the cata$\log$ there arises the question of obtaining it. Again, certain points must be made about this access.

\section{"Only about 17 percent of the Bodlei- an's volumes are to be found on open shelves with direct access to the reader."}

First, there is closed access to most of the library's material. Only about 17 percent of the Bodleian's volumes are to be found on open shelves with direct access to the reader. ${ }^{14}$ This means that an order slip may need to be filled out and given to the reference desk in the Lower Reading Room, which houses the catalogs. The book will be retrieved and returned to the reading room that is requested. Normally, this requires about two hours.

Second, the Bodleian's collections are housed in seven buildings, and thus one needs to know which building is best for the intended research.

The Old Library consists of Duke Humfrey's Library (for western manuscripts and early printed books), the Upper Reading Room (History, English), and Lower Reading Room (classics and catalogs).

The Radcliffe Camera has an upper reading room for undergraduate studies (History) and a lower reading room (for English, Theology, Latin American studies, and government documents).

The New Library has reading rooms for Politics, Philosophy, and Economics (PPE); Slavonic studies; maps; music; Oriental studies and manuscripts; and modern manuscripts; and contains the Indian Institute Library (housed on the top floor of the New Bodleian). Room 132 houses the unique John Johnson Collection of Printed Ephemera. ${ }^{15}$

The Clarendon Building, originally housing university offices, has a reading room and classroom space.

Three of the dependent libraries (to be mentioned later) are housed in separate buildings: the Radcliffe Science Library, Law Library, and Rhodes House Library.

In addition, as storage space in the underground stacks of the Bodleian has filled, space has been acquired in warehouse facilities at Nuneham Courtenay on the outskirts of Oxford. ${ }^{16}$

\section{Conservation}

With materials ranging from papyrus to computer tape, preservation maintenance is an important issue at the Bodleian. It involves all aspects of library operations. When appointed in 1978, the head of the conservation department, Michael Turner, faced the problem of the Bodleian's conservation efforts being scattered under other departmental authorities. ${ }^{17}$ The paper repair workshop was in the Department of Western Manuscripts, for instance. At present it and a conservation workshop (involved in map mounting, etc.), a general bindery, and a conservation bindery for older manuscripts form the Conservation Department. There are normally two or three staff working in each unit. In addition, book service (the pages who retrieve closed stack materials) comes under Turner's jurisdiction. ${ }^{18}$

In the first years as a department, only $£ 25,000(\$ 40,000)$ was left for conservation after salaries were paid. Most of this went for bookbinding. Bodley's central stock was usually bound in-house, while the dependent libraries were given separate grant monies. They sent most of their bindery needs out to commercial firms.

By 1980 several important decisions had been made. Bindery work was stopped on all material except for books on open shelves. These were bound more cheaply in-house. The long-range goal is to bind inhouse all materials for the Bodleian and its dependent libraries.

In place of binding or rebinding items, a major boxing program was instituted using archival-quality materials. The department buys the boxes cut and creased inlaid flat to its specifications from a commercial firm. An item can be boxed for 
80 to 90 pence $(\$ 1.25$ to $\$ 1.50)$ compared to binding the item at $£ 12$ to $£ 15$ ( $\$ 20$ to $\$ 25){ }^{19}$ Phased boxes (developed by former Bodleian staffer Christopher Clarkson when he was at the Library of Congress) are used to house rarer and damaged items. The idea is that these items will remain in these containers until they can either be rebound or have a specially designed box created for their storage. In many cases, due to staff and funding shortages, this temporary phase of storage has become more permanent than planned.

A systematic study of the environmental situation at the Bodleian was undertaken by the University Surveyor's office in the early 1980 s. It issued a report in 1984 with various recommendations for improvement. Over the following three years a new air system plant was installed in the library (New Bodleian) at a cost of one million pounds. This provides better air circulation, heating, and humidity control in the library, especially through the underground storage floors, where most of the libraries' collections are housed.

Currently, excluding salaries, the department receives approximately $£ 100,000$ $(\$ 160,000)$ for conservation needs. Half this sum goes to the central Bodleian libraries and half to the dependent libraries. The Mellon Foundation has recently given a grant for microfilming and renovating the general bindery. ${ }^{20}$ Conservation work is to be the other major recipient of the current fund-raising efforts.

As Turner notes, the Bodleian is basically full today. Books are stored in conditions that cannot be good. This space factor is, as previously noted, already causing keepers of various departments to think twice before accepting new collections, especially large ones.

\section{DEPENDENT LIBRARIES}

Associated with the Bodleian and operated as units of the central library administration are four other important Oxford libraries. They each have a special emphasis, and as such they can be considered types of special libraries.

\section{Indian Institute Library}

Located on the top floor of the New Bod- leian, the library provides books, periodicals, and manuscripts from and related to the countries and history of the Indian subcontinent: India, Pakistan, Sri Lanka, and Burma. Much of the material is open access. Manuscripts (in Sanskrit, among others) must be consulted in the Oriental Reading Room of the New Bodleian.

\section{Law Library}

This library, located in the St. Cross Building, houses the materials related to the study of law. The library is the largest open-shelf facility of its type outside the United States. It is the library in Oxford nearest in design and operation to United States academic libraries and is housed in a building designed for the purpose, unlike many of the library facilities of Oxford.

\section{Radcliffe Science Library}

Located in a large building adjacent to the University Museum, it is one of the leading science libraries. It is largely open access, with a major underground reading room of modern design. Portions of the library contain some fine Eric Gill wood carvings. The large, underground stack area (chiefly compacted shelving) is heavily combed by researchers for the latest scientific entries to the Oxford English Dictionary. A card catalog is available for the library's collection.

\section{Rhodes House Library}

Located in one half of Rhodes House across the street from the Radcliffe Science Library, this is a beautifully designed facility, a mixture of Cotswold cottage and Cape Dutch style, by Sir Ernest Baker (1928). The library is primarily closed access, and there is a large, underground stack area. It specializes in the history and current affairs of the British Commonwealth countries, the United States, and sub-Saharan Africa. Manuscript collections related to these areas are also maintained here, such as those of Cecil Rhodes, the Anti-Slavery Society papers, and the United Society for the Propagation of the Gospel papers. A card catalog by author, partially by subject, and for manuscript collections is maintained. 


\section{CONCLUSION}

The Bodleian Library is unique, as has been noted in the description of its history, organizational design, and collections. It shares with other libraries the modern problems of lack of adequate financial support and lack of space, conser- vation problems, and the dilemma of the rapidly increasing intellectual record. That it and all libraries must attempt, for posterity's sake, to overcome these problems speaks to the duty that Francis Bacon saw for the Bodleian when he spoke of it serving as "an ark to save learning from deluge."

\section{REFERENCES AND NOTES}

1. The quincentennial was celebrated in 1988 and was used to kick off the current fund-raising campaign for the library.

2. Bodleian Library Fact Sheet (Bodleian Library, Oxford, 1988).

3. While the Bodleian has had the right to all copyrighted printed matter in the United Kingdom, in practice through the years there were periods where collection in this area was lax. The other copyright libraries of the United Kingdom are the British Library, the University of Cambridge Library, the National Libraries of Scotland and Wales, and the Library of Trinity College, Dublin.

4. Bodleian Library Fact Sheet.

5. The most recent available figures, taken from the Bodleian Library Fact Sheet, are for 1986-87.

6. David Vaisey, anecdote related to the author, Oxford, May 1989.

7. David Vaisey, anecdote related to the author.

8. Bodley's twenty-two librarians, with date of appointment, are as follows: Thomas James (1600); John Rous (1620); T. Barlow (1652); T. Lockey (1660); Thomas Hyde (1665); J. Hudson (1701); J. Bowles (1719); R. Fysher (1729); H. Owen (1747); J. Price (1768); B. Bandinel (1813); H.O. Coxe (1860); E. W. B. Nicholson (1882); F. Madan (1912); Sir A. Cowley (1919); Sir Edmund Craster (1931); H. R. Creswick (1945); J. N. L. Myres (1948); Robert Shackleton (1966); E. R. S. Fifoot (1979); J. W. Jolliffe (1982); D. G. Vaisey (1986). Note that from the Battle of Waterloo to World War I the Bodleian was served by only four of these men.

9. David Vaisey, conversation with the author, Oxford, May 1989.

10. Charles Mould, conversation with the author, Oxford, May 1989.

11. Mary Clapinson, conversation with the author, Oxford, May 1989.

12. Julian Roberts, conversation with the author, Oxford, May 1989.

13. David Vaisey, conversation with the author, Oxford, May 1989.

14. From Bodleian Library Fact Sheet and comments by David Vaisey. Despite this small percentage, the figure represents a large number of books readily available on open shelving to readers, something more than 850,000 volumes.

15. The John Johnson Collection must be a pack rat's heaven. Housed in a variety of sized boxes and folders, material ranging from playbills, menus, and bottles to a George Bush campaign watch make up a small part of this vast collection, which continues to grow daily.

16. In the gardens of a country house outside Oxford the Bodleian and other Oxford Universityrelated libraries have developed off-site repositories. The Nuneham Courtenay facility was designed for twelve single-story modules to be built in phases over a number of years. At present two of these buildings are in use and a third is currently under construction. It should be completed by the end of this year.

17. Michael Turner, conversation with the author, Oxford, May 1989.

18. The recent creation of a department of reader's services within the Bodleian may result in book service and its pages falling under its jurisdiction rather than under that of the Conservation Department.

19. Figures on the relative costs of boxing versus binding of books are related by Turner.

20. The Mellon grant provides funding of some $\$ 1$ million each to Oxford and Cambridge and $\$ 1.5$ million to the British Library to provide for preservation microfilming of material in each collection. 